\title{
Environment and Behavior
}

http://eab.sagepub.com

\section{Recycling Behavior: A Multidimensional Approach \\ Gonzalo Díaz Meneses and Asunción Beerli Palacio \\ Environment and Behavior 2005; 37; 837 \\ DOI: $10.1177 / 0013916505276742$}

The online version of this article can be found at: http://eab.sagepub.com/cgi/content/abstract/37/6/837

\author{
Published by: \\ (5)SAGE Publications \\ http://www.sagepublications.com \\ On behalf of: \\ Environmental Design Research Association
}

Additional services and information for Environment and Behavior can be found at:

Email Alerts: http://eab.sagepub.com/cgi/alerts

Subscriptions: http://eab.sagepub.com/subscriptions

Reprints: http://www.sagepub.com/journalsReprints.nav

Permissions: http://www.sagepub.com/journalsPermissions.nav

Citations (this article cites 30 articles hosted on the

SAGE Journals Online and HighWire Press platforms):

http://eab.sagepub.com/cgi/content/refs/37/6/837 


\section{RECYCLING BEHAVIOR A Multidimensional Approach}

GONZALO DÍAZ MENESES is a specialist in consumer behavior, particularly in the application of marketing to nonprofit organizations, social marketing, and public policy. He is author of two books and has published more than 30 articles and conference papers. He is a Ph.D. lecturer in Las Palmas of Gran Canaria University, Spain.

ASUNCIÓN BEERLI PALACIO is professor of marketing and chair of the Marketing Department in Las Palmas of Gran Canaria University. She is the author of 10 books and has published more than 60 articles and conference papers in the most prestigious journals of marketing in Spain and Europe. She has advised, carried out research, and conducted executive seminars for a diverse set of organizations including nonprofits and commercial businesses as well as several government agencies.

ABSTRACT: This work centers on the study of consumer recycling roles to examine the sociodemographic and psychographic profile of the distribution of recycling tasks and roles within the household. With this aim in mind, an empirical work was carried out, the results of which suggest that recycling behavior is multidimensional and comprises the undertaking of different roles with different sociodemographic and psychographic causal characteristics. The practical implications of these results can be applied in the implementation of segmentation policies that consider recycling behavior as the product on offer in a discriminate fashion depending on the role to be promoted among the population.

Keywords: recycling behavior; consumer roles; motivation; attitude

Although progress toward solving environmental problems depends more on the consolidation of desirable behaviors, such as that of recycling, than on the development of specific attitudes or motivations, few works focus on the analysis of environmental conduct (Berger, 1997; Van Liere \& Dunlap, 1980). Moreover, when ecological or recycling behavior is measured, it is always considered within the context of a particular tool or product. Sufficient research into environmental conduct as an activity, task, or function that takes place in the home and is not linked to specific materials such as paper or

ENVIRONMENT AND BEHAVIOR, Vol. 37 No. 6, November 2005 837-860

DOI: $10.1177 / 0013916505276742$

(c) 2005 Sage Publications 
glass (Pickett, Kangun, \& Grove, 1993) has not been carried out. Therefore, in this work, we undertake a study of recycling as a multidimensional activity and consider the different functions identified in marketing literature as consumer roles in the household (Díaz, Beerli, \& McCarty, 2003).

In the academic field of marketing, there has been ample research (Dubois $\&$ Rovira, 1999) into a series of roles or functions related to consumption and carried out by members of the household. However, we have not as yet found any application in marketing literature focusing on the recycling sector that specifically mentions the study of consumers' roles within the household. From a theoretical, social marketing perspective, recycling behavior is the product, and the problems to be addressed are how to get consumers to adopt it (Shrum, Lowrey, \& McCarty, 1994) and how the consumer becomes the supplier of raw material produced in the home itself (Fuller, 1978).

The definition of the different recycling roles must fit the inverse nature of the distribution channels for the recovery of waste as conceived by the discipline of recycling marketing. The structure of the roles identified offers the following classification: (a) the influencer; (b) the initiator; (c) the decision maker; (d) the vendor, or person responsible for transporting the waste to the collection points; (e) the persuader; (f) the enforcer, the one who establishes the norms and guidelines for storage, separation, and supply of material to be recycled and ensures that they are followed; and finally $(\mathrm{g})$ the rejecter. Moreover, based on Loudon and Della Bitta (1995), we understand the responsibility of the recycling role as the demands on the time and energy of each member of the household in the distribution of recycling tasks-in other words, the role that each member fulfils. Consequently, we understand that there is a greater burden when the family member assumes more responsibility in fulfilling more recycling roles than the other members of the family.

On that basis, we propose to examine the sociodemographic and psychographic profile of the distribution of tasks and roles of recycling in the home.

\section{REVIEW OF THE LITERATURE}

Arcury, Scollay, and Johnson (1987), on applying the proposals of the expected cultural role, stated that females are usually associated with recycling tasks, because it is an activity that is deeply rooted in the domestic area where women traditionally have more authority of decision and execution. Similarly, from the perspective of the comparative resources theory, the ability to influence is in line with the value attached by each family member to 
guaranteeing the subsistence of the family group. For a long time, the male has been the sole breadwinner, and the so-called family power, or capacity to influence the others, has fallen on him (Alonso, 1999). However, in the last few decades, both the theory of expected cultural roles and that of comparative resources have had to be revised in light of changes that the model of the patriarchal family has undergone (Davis, 1976; Solsona \& Treviño, 1990).

Age is another sociodemographic variable included in the literature as a factor to be considered in relation to environment-friendly behaviors. In their works, Folz and Hazlett (1991), Derksen and Gartrell (1993), and Van Liere and Dunlap (1980) clearly showed the association between ecological behavior and the younger sections of the population. However, as the norm of recycling has become generalized throughout society, so the age variable has lost its discriminatory power (Katzev, Blake, \& Messer, 1993; Mainieri, Barnett, Trisha, Oskamp, \& Unipan, 1997; Oskamp et al., 1991) and its antiestablishment connotations, and young people hardly have any influence on activities that affect the whole family group (Filiatrault \& Ritchie, 1980; Foxman, Tansuhaj, \& Ekstrom, 1989).

Like age, the level of education is given by early research as an antecedent of environmentally friendly behavior. On one hand, a better education opens the possibility of an individual having a greater ability to understand ecological problems (Bigné, 1997; McCarty \& Shrum, 2001). On the other, the comparative resources theory makes it evident that family power does not only fall on the member who contributes the most income to the household but also to those with greater capacities and abilities.

On that basis and on the above-mentioned empirical results that associate the sex, age, and level of education with proenvironmental and recycling norms, we propose the following hypotheses:

Hypothesis 1: Women bear a greater burden of the recycling role than men.

Hypothesis 2: The age of the household member determines the fulfillment of recycling roles in such a way that people whose age is far from the average age of the working population bear a lesser burden of the role than those whose age is roughly that of the average.

Hypothesis 3: The members of the household with a higher level of education bear a greater burden of the recycling role than those members with a lower level of education.

According to the relative investment theory, the structuring of roles within the family unit depends, in the first place, on the motivations and interests of the spouses and secondly on the aims and goals of the other members of the 
family unit. Therefore, control of decisions, or the undertaking of specific roles, will be affected by the relative value that each individual attaches to the product and by his or her position of power within the family structure (Alonso, 1999). As a result, the fulfillment by the family unit of the functions necessary for the recovery of waste will be assumed by those who show more involvement and motivation in the domestic tasks of separating, storing, and supplying the waste. In this sense, the most proven hypothesis to date is that which states that individuals adopt proenvironmental behaviors through ecological motivations (Bigné, 1997; Hopper \& Nielson, 1991; Hornik, Cherian, Madansky, \& Naraya, 1995; Hummel, Levitt, \& Loomis, 1978; Pieters, Bijmolt, Raaij, \& Kruijk, 1998) that mainly concern moral and social imperatives (Black, Stern, \& Elworth, 1985; Schultz \& Stone, 1994; Thogersen, 1996). Intrinsic ecological motivation is an extremely strong force in comparison to other motivations, such as generic motives of seeking social acceptance or influence over others (Hornik et al., 1995) and circumstantial motives stemming from legal imperatives in recent times (Folz \& Hazlett, 1991).

Another approach to the study of recycling motivations stresses the internal behavior inhibitors that discourage the consumer from collaborating in waste separation programs. This line of research conceives motivation as a function of the personal benefits and costs accompanying such behavior (Crosby, Gill, \& Taylor, 1981), which, when applied to recycling, highlights the nuisance and problems of the tasks of classification, storage, and supply within the home rather than the long-term social benefits of the activity (Hummel et al., 1978). Therefore, in line with McCarty and Shrum (1994) and Zikmund and Stanton (1971), we consider that the greatest barrier to recycling is found in the consumer - that is, in what the individual considers within the sphere of his or her personal convenience and comfort, justified mainly by lack of time or space.

Similarly, various works have shown that knowledge of how and where to recycle increases the frequency and volume of waste recovery by citizens (Hornik et al., 1995; Howenstine, 1993; Luyben \& Bailey, 1979). In other words, it can be said that the motivation for carrying out recycling tasks is associated with the individual's capacity or ability (Pieters, 1991) and even with the attribution of efficiency by people in the same social context (Berger \& Corbin, 1992). In fact, the willingness to recycle is negatively related to the number of containers and their location (Katzev et al., 1993). Another factor recognized as an antecedent of environmentally friendly behavior (Minton \& Rose, 1997; Roberts \& Bacon, 1997; Schlegelmilch \& Bohlen, 1996; Zimmer, Stafford, \& Stafford, 1994) and the recovery of waste (Arbuthnot, 
1974, 1977; Derksen \& Gartrell, 1993; Vining \& Ebreo, 1992) is ecological awareness. Despite the ambiguity of the term, there is no doubt that ecological awareness is the most efficient factor in developing environmental behaviors (Chan \& Lau, 2000; Dahle \& Neumayer, 2001; Vining \& Ebreo, 1992). Moreover, ecological awareness increases its antecedent effect when it is measured in a self-perceived way (Schlegelmilch \& Bohlen, 1996; Scholder, 1994), and like other attitudinal patterns, it refers to a specific object of concern (Folz, 1991).

Considering the importance of the ecological motive, negative motivation and ecological awareness are essential antecedents of environment-friendly behaviors in general and of recycling in particular. Based on the theories of comparative resources and of relative investment, we propose the following hypotheses:

Hypothesis 4: Household members with ecological motivation tend to bear a greater burden of the recycling role than those without such motivation.

Hypothesis 5: Family members with negative motivations toward recycling tend to bear a lesser burden of the role than those with less negative motivations.

Hypothesis 6: Household members with ecological attitudes tend to bear a greater burden of the recycling role than those without such attitudes.

\section{ASPECTS OF THE METHODOLOGY}

To attain the proposed objectives, we undertook an empirical work based on personal surveys of a cross-section comprising 358 individuals (see Table 1). The assumed sample error was $\pm 6 \%$ for a reliability interval of $95.5 \%$. The sample was chosen at random with proportional stratification in line with sociodemographic characteristics. The surveys were carried out in January 2002 in situ in the homes of those surveyed by means of a self-administered questionnaire. The entire survey took place in the same metropolitan area to ensure that the waste collective recycling program presented homogeneous levels of convenience and infrastructure. To gather the information, we had the help of 40 volunteers who were studying market research sciences at a university. They arranged their visits before passing on the questionnaires by phone and collecting them personally to check with those surveyed whether they had any problem or difficulty filling in the information required.

The measurement indicators used in the questionnaires comprised different tools. The first was a measurement of motivation to recycle based on a 7item, 5-point, Likert-type scale that asked those surveyed to indicate the 
TABLE 1

The Sample Frequencies

\begin{tabular}{lrc}
\hline & $\mathrm{n}$ & $\%$ \\
\hline Gender & & \\
$\quad$ Male & 189 & 52.8 \\
$\quad$ Female & 169 & 47.2 \\
Age & & \\
18-23 & 99 & 27.2 \\
$24-30$ & 90 & 25.1 \\
$31-45$ & 88 & 24.6 \\
$46-60$ & 62 & 17.3 \\
$>60$ & 19 & 5.3 \\
Level of education & & \\
Without & 16 & 4.5 \\
Primary & 72 & 20.1 \\
Secondary & 130 & 36.3 \\
University (3 years) & 79 & 22.1 \\
University (5 years) & 61 & 17.0 \\
\hline
\end{tabular}

degree to which their motives corresponded to a series of motives. This scale was elaborated based on the works of Bagozzi and Dabholkar (1994) and Hummel et al. (1978). The second indicator measured the recycling role by means of a 7-point, dichotic question that asked those surveyed to indicate whether they had carried out the recycling roles listed (see Table 2). This scale of roles was of the bipolar nature used in the literature to measure the fulfillment of roles (Dubois, 1999; Schiffman \& Lazar, 1997; Solomon, 1997). The third indicator measured negative motivation by means of a 4item, 5-point, Likert-type scale that asked those surveyed to indicate the extent to which they agreed with a series of statements. This scale was elaborated after our review of the literature (Gamba \& Oskamp, 1994; Howenstine, 1993). The fourth indicator measured attitudes of ecological awareness, which included a 7-point, Likert-type scale in which those surveyed were asked to indicate the extent to which they agreed with a series of statements. These scales were based on the literature about ecological awareness and concern (Baldasarre \& Katz, 1992; Schlegelmilch \& Bohlen, 1996).

The recycling material chosen for this research is glass. This choice of material was basically made because it involves a product that (a) requires the active collaboration of the public included in this research, (b) has consolidated distribution channels in our geographical setting thus enabling the public to develop the desired roles without excessive difficulty while also being sufficiently well known, and (c) it is environmentally important from the point of view of sustainability. 
TABLE 2

The Characteristics of Roles Scale

\begin{tabular}{|c|c|}
\hline Role & Item \\
\hline Influencer & $\begin{array}{l}\text { I have provided the greatest amount of information in my household } \\
\text { regarding glass recycling. }\end{array}$ \\
\hline Initiator & $\begin{array}{l}\text { It was I that first proposed the idea of starting to recycle glass in } \\
\text { my household. }\end{array}$ \\
\hline $\begin{array}{l}\text { Decision } \\
\text { maker }\end{array}$ & $\begin{array}{l}\text { It was I who decided that we should begin to recycle the glass refuse } \\
\text { that we were generating in my household. }\end{array}$ \\
\hline Vendor & $\begin{array}{l}\text { I am the member of the household responsible for transporting glass } \\
\text { refuse to the recycling container. }\end{array}$ \\
\hline Persuader & $\begin{array}{l}\text { I was the household member who persuaded the other members of } \\
\text { the need to recycle the glass that we were consuming, and so I have } \\
\text { been the recycling promoter and encourager. }\end{array}$ \\
\hline Enforcer & $\begin{array}{l}\text { I am in charge of ensuring that our household glass-recycling rules are } \\
\text { obeyed. }\end{array}$ \\
\hline Rejecter & $\begin{array}{l}\text { I have been the household member who has most frequently } \\
\text { expressed the opinion that we should not concern ourselves with } \\
\text { glass recycling, as it only causes additional household problems. }\end{array}$ \\
\hline
\end{tabular}

\section{ANALYSIS OF RESULTS}

With the aim of checking Hypotheses 1, 2, and 3, we did an analysis of contingency tables between each of the sociodemographic variables and the recycling roles. The first variable analyzed was gender, and in light of the results obtained, we can state that women carry out the roles of influencer, initiator, decision maker, persuader, and enforcer more often than men, although the difference is very small (see Table 3 ). Therefore, we can state that women bear a greater burden of the recycling role than men, and the first hypothesis is verified. However, the roles of vendor and rejecter show no statistically significant differences related to gender.

With reference to the relationship between age and the distribution of recycling roles in the home, statistically significant results were obtained for the roles of initiator, decision maker, persuader, enforcer, rejecter, and influencer, albeit to a small degree (see Table 4). The role of influencer is hardly ever adopted by those younger than 60; likewise, the role of initiator was hardly ever undertaken by those younger than 23 . In addition, the initiator role is often played by people between the ages of 31 and 45 . The decision maker is usually between 46 and 60 years old and is hardly ever younger than 23. Moreover, the roles of enforcer, persuader, and rejecter are never taken by anyone younger than 23. In addition, the roles of enforcer and persuader are played by people between the ages of 31 and 45 , and the rejecter is played by 
TABLE 3

Analysis of Contingency Tables Between Gender and the Recycling Roles

\begin{tabular}{|c|c|c|c|c|c|c|}
\hline & \multicolumn{2}{|c|}{ Male } & \multicolumn{2}{|c|}{ Female } & \multicolumn{2}{|c|}{$\begin{array}{c}\text { Contingency } \\
\text { Coefficient }\end{array}$} \\
\hline & $\mathrm{n}$ & Residual & $\mathrm{n}$ & Residual & Value & $\mathrm{p}$ \\
\hline Influencer & & & & & .140 & .007 \\
\hline No & 96 & 2.7 & 62 & -2.7 & & \\
\hline Yes & 93 & -2.7 & 107 & 2.7 & & \\
\hline Initiator & & & & & .141 & .007 \\
\hline No & 103 & 2.7 & 68 & -2.7 & & \\
\hline Yes & 86 & -2.7 & 101 & 2.7 & & \\
\hline Decision maker & & & & & .146 & .005 \\
\hline No & 96 & 2.8 & 61 & -2.8 & & \\
\hline Yes & 93 & -2.8 & 108 & 2.8 & & \\
\hline Vendor & & & & & .074 & .160 \\
\hline No & 68 & 1.4 & 49 & -1.4 & & \\
\hline Yes & 121 & -1.4 & 120 & 1.4 & & \\
\hline Persuader & & & & & .143 & .006 \\
\hline No & 110 & 2.7 & 74 & -2.7 & & \\
\hline Yes & 79 & -2.7 & 95 & 2.7 & & \\
\hline Enforcer & & & & & .142 & .007 \\
\hline No & 102 & 2.7 & 67 & -2.7 & & \\
\hline Yes & 87 & -2.7 & 102 & 2.7 & & \\
\hline Rejecter & & & & & .003 & .961 \\
\hline No & 136 & 0.0 & 122 & 0.0 & & \\
\hline Yes & 53 & 0.0 & 47 & 0.0 & & \\
\hline
\end{tabular}

people between the ages of 46 and 60. Finally, the persuader role is hardly ever adopted by those older than 60 . Therefore, it can be stated that the age of the household member determines the fulfillment of recycling roles in such a way that people whose age is far from the working population's average bear a lesser burden of the role than those whose age is roughly that of the average; hence the second hypothesis is verified. However, similar to the case of the variable of age, the function of vendor did not show sufficient statistical significance to be linked to a particular age group.

As is shown by the contingency coefficient in Table 5, unlike the other sociodemographic variables, the level of education does not affect the adoption of the roles of influencer and vendor (see Table 5). The only roles that show a statistically significant relationship with the level of education are those of persuader and rejecter, although in opposing ways. Whereas the rejecter only has a primary education and not a secondary education, the persuader usually has a university education. In addition, based on results of 


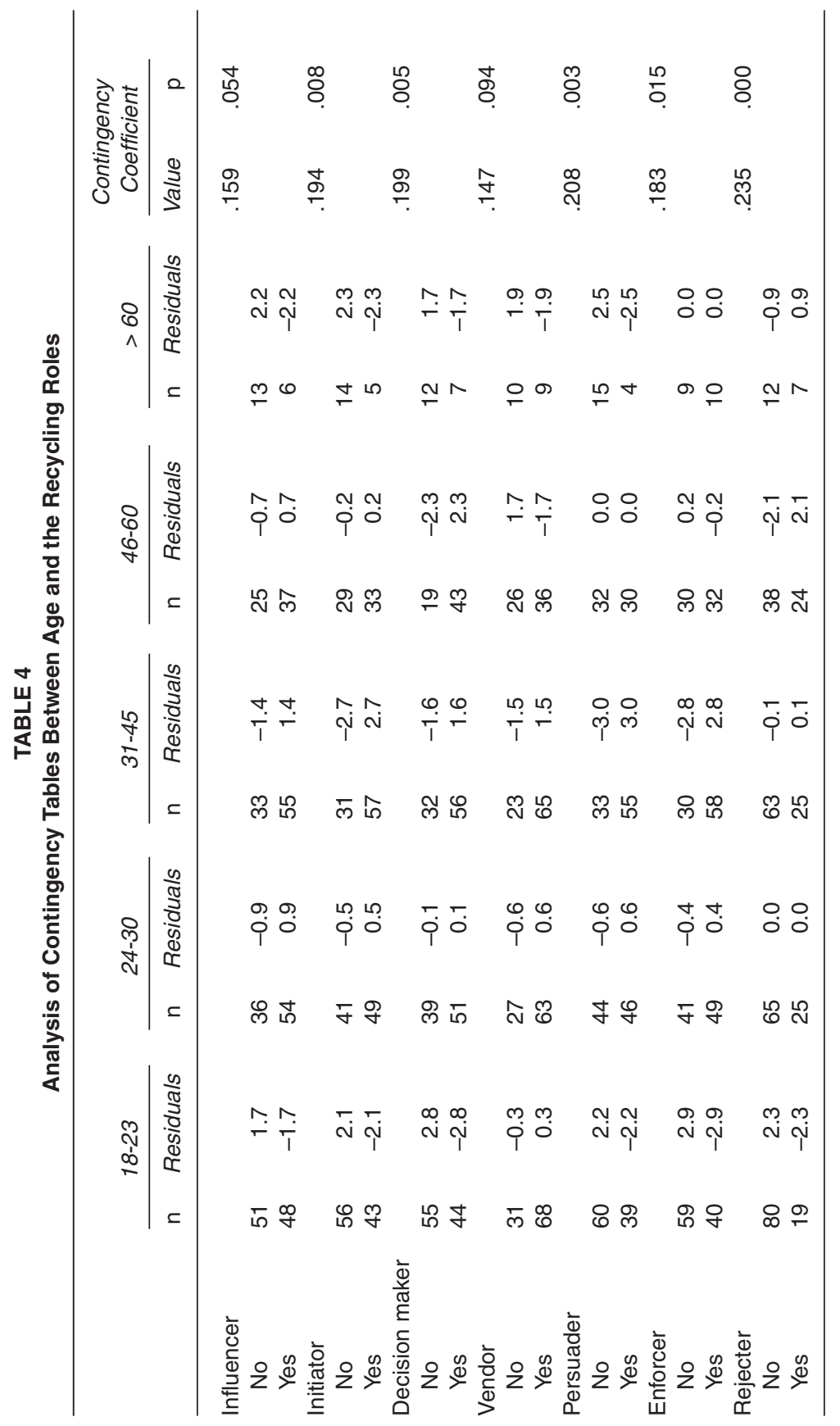




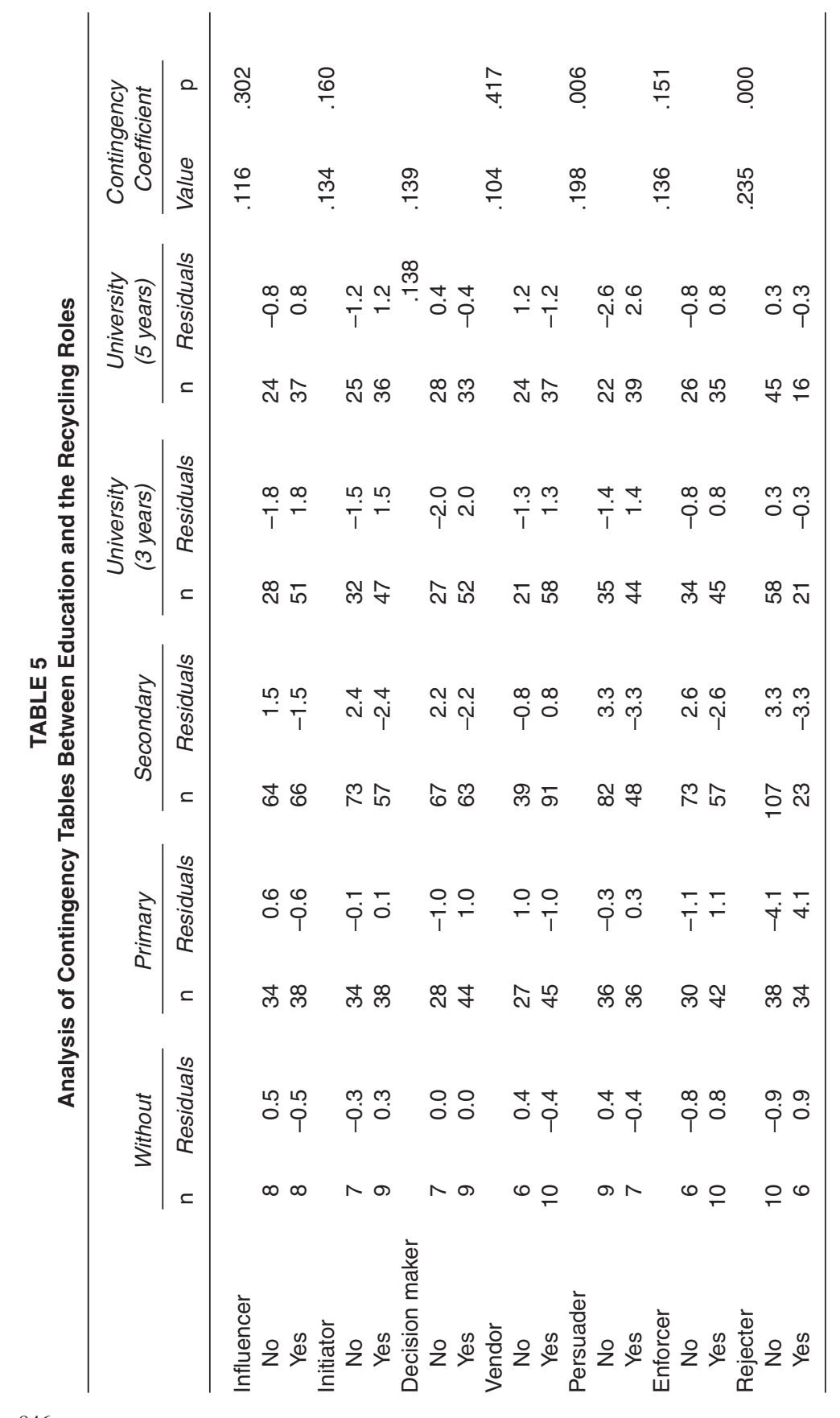


corrected residuals, we can consider that the roles of initiator, decision maker, and enforcer achieve a statistically significant relationship, although only moderately. To be more specific, all of these roles do not have a secondary education level, and furthermore, the role of decision maker frequently has a university degree. However, these results lead us to contradict the supposition that the members of the household with a higher level of education bear a greater burden of the recycling role than those members with a lower educational level, and therefore, the hypothesis is not verified in the least.

Before checking Hypotheses 4, 5, and 6, we first carried out a reliability analysis of the scales of Positive Motivation, Negative Motivation, and Ecological Awareness Attitudes whose Cronbach's alphas were .74, .75, and .53, respectively. Then we ran a factorial analysis of principal components with Varimax rotation on the scale of Positive Motivation with an explained variance of $73.5 \%$, whereas the explained variance for Negative Motivation was 83.09\% and that of Ecological Awareness Attitudes was 76.92\%. Three factors were extracted from the Positive Motivation scale and from the scale of Ecological Awareness Attitudes, whereas two factors with values of above 1 were extracted from the Negative Motivation scale, all of which we will now comment on. The motivation to recycle is defined by three dimensions, with the first and the second explaining a significant percentage of the variance, $41.546 \%$ and $20.20 \%$, respectively. The first factor we have named motivation by ecological self-realization, because it is made up of needs of an environmental nature and self-satisfaction. We labeled the second factor social responsibility, and this explains $20.20 \%$ of the total variance. The third factor refers to social norms, because it is explained by motives of social acceptance and obedience, and this explains $11.7 \%$ of the total variance (Table 6).

Two factors were extracted from the Negative Motivation scale. The first factor is explained by aspects linked to the consumer's lifestyle and explained $42.5 \%$ of the variance. The second factor is defined by variables related to the convenience and knowledge of the location of containers for separated waste, and we have called it convenience. This factor explains $40.5 \%$ of the variance (Table 7).

The factorial analysis of the scale of Ecological Awareness Attitudes resulted in three factors. The first explained $43.1 \%$ of the variance, the second $21.18 \%$, and the third $12.6 \%$. We called the first factor environmental knowledge because it comprises variables linked to knowledge of environmental problems. The second factor is linked to a perception of the environmental problem related to other matters of concern and was labeled environmental concern. The third was labeled ecological involvement because it is defined by variables showing the degree of importance and gravity attached to problems related to the environmental decline (Table 8). 
TABLE 6

Exploratory Analyses of Motivation

\begin{tabular}{|c|c|c|c|c|}
\hline \multirow[b]{2}{*}{ Variable } & & \multicolumn{3}{|c|}{ Factors } \\
\hline & & $F 1$ & F2 & F3 \\
\hline To protect and save the environment & & $.82^{\mathrm{a}}$ & .17 & .03 \\
\hline Because of love of nature & & $.85^{\mathrm{a}}$ & .11 & .13 \\
\hline Because of ecological convictions & & $.75^{\mathrm{a}}$ & .26 & .03 \\
\hline It is what I should do & & .20 & $.84^{\mathrm{a}}$ & .16 \\
\hline To help and collaborate with society & & .24 & $.83^{\mathrm{a}}$ & .14 \\
\hline To comply with the norms of my household & & .10 & .25 & $.78^{\mathrm{a}}$ \\
\hline Because it pleases me to do what I am told & & .01 & .04 & $.88^{\mathrm{a}}$ \\
\hline Explained variance & $73.528 \%$ & & & \\
\hline Kaiser Meyer Olkin & 0.760 & & & \\
\hline Bartlett & 670.401 & & & \\
\hline$p$ & .0000 & & & \\
\hline
\end{tabular}

NOTE: F1 = ecological self-realization; F2 = social responsibility; F3 = social norm.

a. Denotes that the factor is explained by the item.

TABLE 7

Exploratory Analyses of Negative Motivation

\begin{tabular}{ll}
\hline Variable & \multicolumn{2}{c}{ Factors } \\
\cline { 2 - 2 } & F1 F2 \\
\hline
\end{tabular}

Because my household generates little glass waste, it remains in the house for a long time, generates a bad smell, and so discourages me from recycling.

$.89^{\mathrm{a}} \quad .22$

The bad appearance and unattractiveness in my house leads me to reject the recycling of glass.

The distance between my house and the recycling container makes it inconvenient for me to recycle glass.

There are no recycling containers where I live, which prevents me from recycling.

Explained variance

$83.09 \%$

0.621

Kaiser Meyer Olkin

Bartlett

469.945

$p$

.0000

NOTE: F1 = lifestyle; F2 = convenience.

a. Denotes that the factor is explained by the item.

With the aim of checking Hypotheses 4, 5, and 6 as set out in section 2, we carried out a logistic regression analysis based on the factors extracted from the factorial analyses of positive motivation, negative motivation, and ecological awareness attitudes and the recycling roles. First, the empirical results 
TABLE 8

Exploratory Analyses of Ecological Attitudes

\begin{tabular}{|c|c|c|c|}
\hline \multirow[b]{2}{*}{ Variable } & \multicolumn{3}{|c|}{ Factors } \\
\hline & $F 1$ & $F 2$ & F3 \\
\hline In general, I know how not to damage the ecosystem. & $.77^{\mathrm{a}}$ & .17 & -.13 \\
\hline $\begin{array}{l}\text { In general, I can distinguish between what is good and } \\
\text { what is bad for the environment. }\end{array}$ & $.72^{\mathrm{a}}$ & .30 & .05 \\
\hline I am aware of the ecological matters concerning the Earth. & $.86^{\mathrm{a}}$ & .14 & -.07 \\
\hline $\begin{array}{l}\text { There are more important things in today's society than } \\
\text { ecological problems. }\end{array}$ & -.04 & -.12 & $.85^{\mathrm{a}}$ \\
\hline $\begin{array}{l}\text { Many questions worry me more than the deterioration of } \\
\text { nature. }\end{array}$ & -.08 & -.07 & $.86^{\mathrm{a}}$ \\
\hline $\begin{array}{l}\text { It is essential to protect the environment to ensure the } \\
\text { safety and well-being of everyone. }\end{array}$ & .27 & $.80^{\mathrm{a}}$ & -.09 \\
\hline $\begin{array}{l}\text { I believe that the Earth will not be able to support the } \\
\text { exploitation of its resources if things continue as now. }\end{array}$ & .21 & $.75^{\mathrm{a}}$ & -.09 \\
\hline Explained variance $\quad 76.9 \%$ & & & \\
\hline Kaiser Meyer Olkin & & & \\
\hline Bartlett & & & \\
\hline .0000 & & & \\
\hline
\end{tabular}

NOTE: F1 = environmental knowledge; F2 = environmental concern; F3 = ecological involvement. a. Denotes that the factor is explained by the item.

about motivations to recycle permit us to state that ecological self-realization is the factor most closely linked to the carrying out of recycling roles. In that sense, we can see that this motivation appears, above all, as an antecedent of the roles of, in descending order, influencer, persuader, initiator, enforcer, vendor, and decision maker and with a negative association to the rejecter. Similarly, the motive linked to the presence of convictions of social responsibility show sufficient statistical significance to explain the presence of all the roles favoring a recycling behavior with the exception of the role of vendor. However, this absence explains the presence of the role of rejecter.

Furthermore, the adoption of a recycling conduct is not associated with compliance with the social norm, because it requires sacrifices in terms of space and that implies high commitment. Such commitment would normally entail lower levels of involvement with the environmental recycling cause. However, the role of the rejecter shows greater concern for the social norm (see Table 9).

Thus, the results lead us to verify the fourth hypothesis, which states that household members with ecological motivation tend to bear a greater burden of the recycling role than those without such motivation.

The empirical evidence resulting from the statistical analysis related to the two factors of negative motivation and to the recycling roles allows us to infer 
850 ENVIRONMENT AND BEHAVIOR / November 2005

TABLE 9

Logistic Regression: Recycling Roles and Motivation

\begin{tabular}{|c|c|c|c|c|}
\hline Variable & Coefficient B & $\operatorname{Exp}(\mathrm{B})$ & Wald & $\mathrm{p}$ \\
\hline \multicolumn{5}{|l|}{ Influencer } \\
\hline F1 & .968 & 2.633 & 50.7723 & .000 \\
\hline $\mathrm{F} 2$ & .384 & 1.469 & 10.343 & .001 \\
\hline F3 & .099 & 1.104 & 0.669 & .414 \\
\hline Constant & 0.282 & & 5.614 & 0.018 \\
\hline Goodness of fit & 417.815 & & & \\
\hline$\%$ correct & 67.3 & & & \\
\hline \multicolumn{5}{|l|}{ Initiator } \\
\hline $\mathrm{F} 1$ & .724 & 2.062 & 34.047 & .000 \\
\hline $\mathrm{F} 2$ & .429 & 1.536 & 13.568 & .000 \\
\hline F3 & .137 & 1.147 & 1.414 & .234 \\
\hline Constant & 0.101 & & 0.776 & 0.378 \\
\hline Goodness of fit & 442.201 & & & \\
\hline$\%$ correct & 64.5 & & & \\
\hline \multicolumn{5}{|l|}{ Decision maker } \\
\hline $\mathrm{F} 1$ & .543 & 1.722 & 21.485 & .000 \\
\hline $\mathrm{F} 2$ & .367 & 1.443 & 10.496 & .001 \\
\hline F3 & .183 & 1.200 & 2.573 & .109 \\
\hline Constant & 0.273 & & 5.887 & 0.015 \\
\hline Goodness of fit & 455.085 & & & \\
\hline \% correct & 63.4 & & & \\
\hline \multicolumn{5}{|l|}{ Vendor } \\
\hline F1 & .613 & 1.845 & 24.968 & .000 \\
\hline $\mathrm{F} 2$ & .020 & 1.020 & 0.028 & .868 \\
\hline F3 & .081 & 1.084 & 0.456 & .499 \\
\hline Constant & 0.782 & & 42.920 & 0.000 \\
\hline Goodness of fit & 424.686 & & & \\
\hline$\%$ correct & 67.9 & & & \\
\hline \multicolumn{5}{|l|}{ Persuader } \\
\hline F1 & .727 & 2.069 & 34.167 & .000 \\
\hline $\mathrm{F} 2$ & .399 & 1.490 & 11.789 & .001 \\
\hline F3 & .176 & 1.193 & 2.347 & .126 \\
\hline Constant & -0.068 & & 0.351 & 0.554 \\
\hline Goodness of fit & 443.113 & & & \\
\hline \% correct & 64.0 & & & \\
\hline \multicolumn{5}{|l|}{ Enforcer } \\
\hline F1 & .615 & 1.850 & 26.712 & .000 \\
\hline $\mathrm{F} 2$ & .325 & 1.385 & 8.298 & .004 \\
\hline F3 & .154 & 1.167 & 1.860 & .173 \\
\hline Constant & 0.123 & & 1.209 & 0.272 \\
\hline Goodness of fit & 455.895 & & & \\
\hline$\%$ correct & 64.5 & & & \\
\hline
\end{tabular}


TABLE 9 (continued)

\begin{tabular}{lcccc}
\hline Variable & Coefficient B & Exp (B) & Wald & $\mathrm{p}$ \\
\hline Rejecter & & & & \\
F1 & -.333 & 0.717 & 7.283 & .007 \\
F2 & -.375 & 0.687 & 8.689 & .003 \\
F3 & .611 & 1.842 & 22.514 & .000 \\
Constant & -1.071 & & 67.165 & 0.000 \\
Goodness of fit & 385.266 & & & \\
\% correct & 74.6 & & & \\
\hline NOTE: F1 = ecological self-realization; F2 = social responsibility; F3 = social norm.
\end{tabular}

NOTE: F1 = ecological self-realization; F2 = social responsibility; F3 = social norm.

that the motives of convenience explain the refusal to adopt the role of initiator and vendor. On the other hand, the role of rejecter is favored when recycling is not convenient or easy (Table 10). Finally, the roles of influencer, decision maker, persuader, and enforcer are not associated with convenience.

Furthermore, the negative motivation factor related to the family members' lifestyles inhibits the adoption of all the roles identified as favoring recycling, except that of enforcer. However, the family members' lifestyle is an antecedent of the rejecter role. All this leads us to confirm, albeit to a moderate degree, the fifth hypothesis, which states that family members with negative motivations toward recycling tend to bear a lesser burden of the role than those with less negative motivations.

Regarding the results obtained from the logistic regression analysis of the three factors of an ecologically aware attitude that were identified in the factorial analysis and the distribution of recycling roles, we note that the factor referring to an attitude of environmental knowledge appears to be associated with all the roles except that of rejecter and explains the adoption of, in the following order, the roles of influencer, initiator, decision maker, persuader, enforcer, and, to a lesser extent, seller. On the other hand, the role of rejecter does not have a sufficient statistically significant relationship with this factor, possibly because there are other positive or negative motivations that better explain the role of rejecter (see Table 11).

The factor related to environmental concern is only an antecedent of three roles-initiator, persuader, and influencer-with functions that appear to be associated with the special importance of ecological problems in comparison with other matters, unlike the role of rejecter, the adoption of which is more probable when the consumer attaches no more importance to environmental problems than to other problems. The other identified roles do not have a sufficient statistically significant relationship with the factor of environmentally concerned attitude. 
852 ENVIRONMENT AND BEHAVIOR / November 2005

TABLE 10

Logistic Regression: Recycling Roles and Negative Motivation

\begin{tabular}{|c|c|c|c|c|}
\hline Variable & Coefficient B & $\operatorname{Exp}(\mathrm{B})$ & Wald & $\mathrm{p}$ \\
\hline \multicolumn{5}{|l|}{ Influencer } \\
\hline F1 & -.475 & 0.622 & 17.973 & .000 \\
\hline $\mathrm{F} 2$ & -.111 & 0.895 & 1.014 & .314 \\
\hline Constant & 0.245 & & 5.007 & 0.025 \\
\hline Goodness of fit & 471.342 & & & \\
\hline$\%$ correct & 62.6 & & & \\
\hline \multicolumn{5}{|l|}{ Initiator } \\
\hline F1 & -.442 & 0.643 & 15.672 & .000 \\
\hline $\mathrm{F} 2$ & -.255 & 0.775 & 5.475 & .019 \\
\hline Constant & 0.092 & & 0.710 & 0.400 \\
\hline Goodness of fit & 473.754 & & & \\
\hline$\%$ correct & 60.3 & & & \\
\hline \multicolumn{5}{|l|}{ Decision maker } \\
\hline F1 & -.472 & 0.624 & 17.783 & .000 \\
\hline $\mathrm{F} 2$ & -.184 & 0.832 & 2.815 & .093 \\
\hline Constant & 0.259 & & 5.534 & 0.019 \\
\hline Goodness of fit & 469.390 & & & \\
\hline$\%$ correct & 63.4 & & & \\
\hline \multicolumn{5}{|l|}{ Vendor } \\
\hline F1 & -.269 & 0.764 & 5.696 & .017 \\
\hline $\mathrm{F} 2$ & -.231 & 0.793 & 4.128 & .042 \\
\hline Constant & 0.744 & & 41.799 & 0.000 \\
\hline Goodness of fit & 442.707 & & & \\
\hline$\%$ correct & 66.8 & & & \\
\hline \multicolumn{5}{|l|}{ Persuader } \\
\hline $\mathrm{F} 1$ & -.450 & 0.638 & 16.032 & .000 \\
\hline $\mathrm{F} 2$ & -.181 & 0.835 & 2.763 & .096 \\
\hline Constant & -0.063 & & 0.331 & 0.565 \\
\hline Goodness of fit & 476.327 & & & \\
\hline$\%$ correct & 58.1 & & & \\
\hline \multicolumn{5}{|l|}{ Enforcer } \\
\hline $\mathrm{F} 1$ & -.170 & 0.844 & 2.528 & .112 \\
\hline F2 & -.167 & 0.846 & 2.449 & .118 \\
\hline Constant & 0.113 & & 1.128 & 0.288 \\
\hline Goodness of fit & 490.189 & & & \\
\hline$\%$ correct & 55.3 & & & \\
\hline \multicolumn{5}{|l|}{ Rejecter } \\
\hline $\mathrm{F} 1$ & .294 & 1.342 & 6.135 & .013 \\
\hline F2 & .479 & 1.615 & 15.732 & .000 \\
\hline Constant & -1.015 & & 65.990 & 0.000 \\
\hline Goodness of fit & 402.453 & & & \\
\hline$\%$ correct & 71.2 & & & \\
\hline
\end{tabular}

NOTE: F1 = lifestyle; F2 = convenience. 
TABLE 11

Logistic Regression: Recycling Roles and Attitudes

\begin{tabular}{|c|c|c|c|c|}
\hline Variable & Coefficient B & $\operatorname{Exp}(\mathrm{B})$ & Wald & $\mathrm{p}$ \\
\hline \multicolumn{5}{|l|}{ Influencer } \\
\hline F1 & .678 & 1.969 & 29.847 & .000 \\
\hline $\mathrm{F} 2$ & -.235 & 0.790 & 4.037 & .045 \\
\hline F3 & .369 & 1.446 & 10.293 & .0101 \\
\hline Constant & 0.265 & & 5.389 & 0.020 \\
\hline Goodness of fit & 443.516 & & & \\
\hline$\%$ correct & 63.1 & & & \\
\hline \multicolumn{5}{|l|}{ Initiator } \\
\hline $\mathrm{F} 1$ & .524 & 1.689 & 19.961 & .000 \\
\hline $\mathrm{F} 2$ & -.288 & 0.750 & 6.406 & .011 \\
\hline F3 & .280 & 1.323 & 6.278 & .012 \\
\hline Constant & 0.096 & & 0.743 & 0.389 \\
\hline Goodness of fit & 461.552 & & & \\
\hline$\%$ correct & 58.4 & & & \\
\hline \multicolumn{5}{|l|}{ Decision maker } \\
\hline $\mathrm{F} 1$ & .480 & 1.616 & 17.181 & .000 \\
\hline $\mathrm{F} 2$ & -.169 & 0.845 & 2.241 & .134 \\
\hline F3 & .321 & 1.378 & 8.267 & .004 \\
\hline Constant & 0.266 & & 5.711 & 0.017 \\
\hline Goodness of fit & 462.137 & & & \\
\hline \% correct & 59.8 & & & \\
\hline \multicolumn{5}{|l|}{ Vendor } \\
\hline F1 & .368 & 1.445 & 9.892 & .002 \\
\hline $\mathrm{F} 2$ & -.116 & 0.890 & 0.985 & .321 \\
\hline F3 & .239 & 1.270 & 4.406 & .036 \\
\hline Constant & 0.756 & & 42.206 & 0.0000 \\
\hline Goodness of fit & 436.944 & & & \\
\hline$\%$ correct & 68.4 & & & \\
\hline \multicolumn{5}{|l|}{ Persuader } \\
\hline F1 & .473 & 1.604 & 16.710 & .000 \\
\hline $\mathrm{F} 2$ & -.281 & 0.755 & 6.261 & .012 \\
\hline F3 & .229 & 1.257 & 4.268 & .039 \\
\hline Constant & -0.063 & & 0.323 & 0.570 \\
\hline Goodness of fit & 467.789 & & & \\
\hline \% correct & 59.5 & & & \\
\hline \multicolumn{5}{|l|}{ Enforcer } \\
\hline F1 & .437 & 1.548 & 14.752 & .000 \\
\hline $\mathrm{F} 2$ & -.143 & 0.867 & 1.666 & .197 \\
\hline F3 & .289 & 1.335 & 6.842 & .009 \\
\hline Constant & 0.118 & & 1.156 & 0.282 \\
\hline Goodness of fit & 471.112 & & & \\
\hline$\%$ correct & 61.5 & & & \\
\hline
\end{tabular}


TABLE 11 (continued)

\begin{tabular}{lcccc}
\hline Variable & Coefficient B & Exp (B) & Wald & $\mathrm{p}$ \\
\hline Rejecter & & & & \\
F1 & -.179 & 0.836 & 2.185 & .139 \\
F2 & .345 & 1.412 & 7.666 & .006 \\
F3 & -.364 & 0.695 & 9.212 & .002 \\
Constant & -1.007 & & 65.915 & 0.000 \\
Goodness of fit & 405.009 & & & \\
\% correct & 73.2 & & & \\
\hline \multicolumn{4}{l}{ NOTE: F1 = environmental knowledge; F2 = environmental concern; F3 = ecological involvement. }
\end{tabular}

Last, the factor defined by an attitude of ecological involvement is associated with the adoption of all of the roles, although this association is weaker than in the case of an attitude of prior environmental knowledge. The roles of influencer and decision maker seem more probable when the consumer is involved in ecological matters, as do the roles of seller, enforcer, initiator, and persuader, although with a lower statistical significance. However, the role of rejecter is seen to be associated with scant consideration of the importance of ecological questions, probably because of the strong relationship usually existing between motivation and involvement. Thus, those results permit us to soundly assert that household members with ecological attitudes tend to bear a greater burden of the recycling role than those without such attitudes, and so the sixth hypothesis is confirmed.

\section{CONCLUSIONS}

The empirical evidence obtained in this work permits us to affirm that the members of a household carry out different roles in the recovery of waste. At the same time, those roles are explained by specific sociodemographic and psychographic factors, which means considering different antecedents for each recycling role. In addition to this, these results lead us to conclude that recycling behavior is multidimensional and comprises the undertaking of different roles with different causal characteristics. To be more specific, we can describe every role as can be seen in Table 12 .

The practical implications of these results can be applied in the implementation of segmentation policies that consider recycling behavior as the product on offer in a discriminate fashion depending on the role to be promoted among the population. For example, to neutralize the rejecting role, it is 


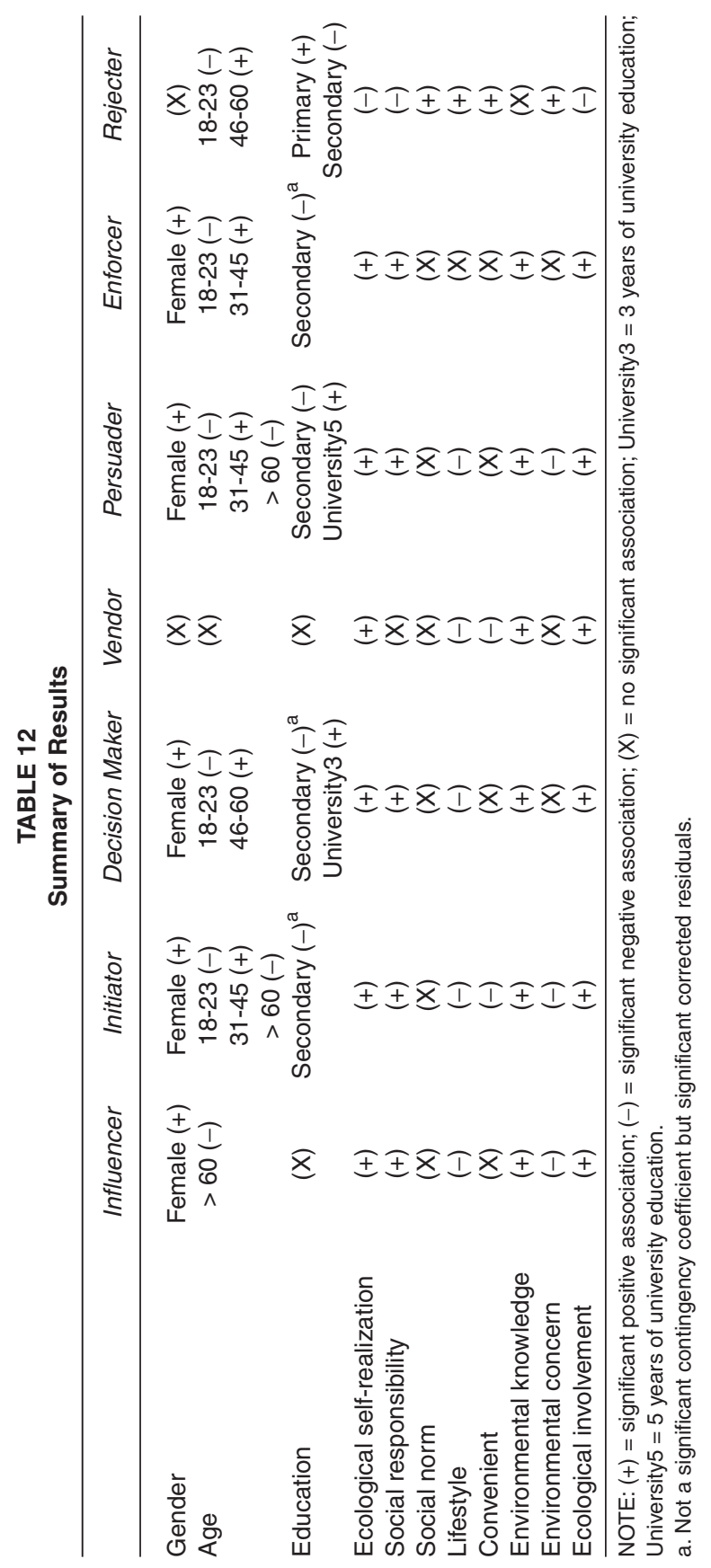


important to know that ecological conscience is not a decisive attitude, but only environmental concern and involvement are suitable to overcome this negative recycling function. Thus, when advertising messages are oriented toward the reluctant, they should stress environmental damage information so that this target develops environmental concern. In fact, it does not seem worthwhile to provide endless information about general ecological matters as long as ecological conscience does not relate to the reluctant function. Following this, it could be more effective and efficient to concentrate our marketing efforts on a specific profile: mid-age (aged 46-60) persons with primary education levels. They are the hard-core reluctant group, and we know they perceive barriers related to their lifestyle and convenience, maybe because they have a low level in all the positive motives toward recycling and the environment. Another possible way to fight against reluctance consists of working on social norms. Clearly, as a consequence of the fact that perceived norms have a substantial impact on people who play a rejecting role, we recommend identifying the other significant third parties in the household to send them messages to consider the importance of waste reduction. This action could be appropriate, as the rejecting role is very affected by this social pressure.

Furthermore, if we wanted to perform any favoring role to recycle, we would have to spread more ecological conscience or environmental knowledge, ecological involvement, and ecological self-realization among citizens. Thus, these components are essential in any design for building effective programs, and therefore, we recommend that citizens be made aware through the educational system. However, because environmental concern is not statistically associated with the decision maker, vendor, and enforcer, the treatment with this attitude is more specific to some particular roles. In other words, ecological concern is only suitable to develop the influencer, initiator, and persuader recycling roles. Thus, for example, the development of a persuasion strategy for these specific roles should begin by including content related to environmental damage and ecological disasters in messages. Based on sociodemographic characteristics analysis, to identify the influencer is more difficult than identifying the initiator and the persuader, who are women aged between 31 and 45 .

If a program is to be effective, careful consideration needs to be given to strategy development related to the decision makers, vendors, and enforcers. In reference to decision makers, the critical element is also to identify his or her sociodemographic profile, and once this identification is completed, we are ready to pilot the strategy. Thus, it is important to know that decision makers are very frequently females between 46 and 60 years of age with a 
a university degree. To encourage the adoption of a favoring decision on this particular segment, any message evoking social responsibility must be effective. However, according to the consumer marketing literature, the arousal of the decision maker must be due to different aspects based on family structure and cultural distribution of power in the household. Likewise, the enforcer is motivated by social responsibility. Therefore, communications clarifying the collective importance of recycling and how recycling affects society must be what is best to transmit. The target is characterized by younger women between 31 and 45 than the decision maker and with a higher level of university education. Finally, our results lead us to conclude that there is not a specific profile to describe the vendor. However, it is very important to point out that compared to the other roles, the vendor is very concerned with convenience. Therefore, logically, this role can be encouraged by shortening the distance between the household and the trash container and in general by facilitating the task of transporting the recycling residuals from the household. In summary, successful environmental public policy makers should be aware of the possible ways in which people divide up their recycling roles among each other. Therefore, we suggest adapting environmental program efforts to the type of role specialization.

This work also opens the way for different lines of research to be developed, which can expand the description of each of the roles while examining their antecedents in depth. Indeed, according to the literature, there are more determinants of people's roles in the home (values, customs, traditions, and other cultural aspects), reference groups and personal worth, and personality, race, and genetics in addition to numerous characteristics related to contexts such as time, place of residence, and so on. Furthermore, these seven roles are not the only ones of interest, because there are many other essential tasks within the context of recycling in the home, for example, the separation and storage of waste-something that this work has not dealt with. It would also seem desirable to propose that the objectives of this work be applied to other products such as the recycling of paper, cardboard, or batteries. Finally, we consider that it would be of interest to tackle the analysis of the structure of roles from an industrial marketing perspective that centers its study on tasks undertaken by individual members of formal organizations, for example, companies or public institutions. This kind of organizational behavior must be distributed into similar roles, and as a consequence, its organizational nature is explained by different factors. Therefore the analysis must focus on similar roles such as influencer, initiator, and decision maker and on different variables such as formal hierarchies, brands and products to commercialize, and relationships between providers, competitors, clients, and employees. 


\section{REFERENCES}

Alonso, J. (1999). Comportamiento del consumidor [Consumer behavior]. Madrid, Spain: ESIC Editorial.

Arbuthnot, J. (1974). Environmental knowledge and recycling behavior as a function of attitudes and personality characteristics. Personality and Social Psychology, 1, 119-121.

Arbuthnot, J. (1977). The roles of attitudinal and personality variables in prediction of environmental behavior and knowledge. Environment and Behavior, 9(2), 217-232.

Arcury, T., Scollay, S., \& Johnson, T. (1987). Sex differences in environmental concern and knowledge: The case of acid rain. Sex Roles, 16(9/10), 463-473.

Bagozzi, R., \& Dabholkar, P. (1994). Consumer recycling goals and their effect on decisions to recycle: A mean-end chain analysis. Psychology and Marketing, 11, 1-28.

Baldassare, M., \& Katz, C. (1992). The personal threat of environmental problems as predictor of environmental practices. Environment and Behavior, 24(5), 602-616.

Black, J., Stern, P., \& Elworth, J. (1985). Personal and contextual influences on household energy adaptations. Journal of Applied Psychology, 70, 3-21.

Berger, I. (1997). The demographics of recycling and the structure of environmental behavior. Environment and Behavior, 29(4), 515-531.

Berger, I., \& Corbin, R. (1992). Perceived consumer effectiveness and faith in others as moderators of environmentally responsible behaviors. Journal of Public Policy and Marketing, 11(2), 79-89.

Bigné, E. (1997). El consumidor verde: Bases de un modelo de comportamiento [The green consumer: The bases for a model of behavior]. ESIC Market, 97, 237-251.

Chan, R., \& Lau, L. (2000). Antecedents of green purchases: A survey in China. Journal of Consumer Marketing, 17(4), 338-357.

Crosby, L., Gill, J., \& Taylor, J. (1981). Consumer voter behavior in the passage of Michigan container law. Journal of Marketing, 45, 19-32.

Dahle, M., \& Neumayer, E. (2001). Overcoming barriers to campus greening: A survey among higher educational institutions in London. International Journal of Higher Education, 2(2), 139-159.

Davis, H. (1976). Decision making within the household. Journal of Consumer Research, 2, 241260.

Derksen, L., \& Gartrell, J. (1993). The social context of recycling. American Sociological Review, 58, 434-442.

Díaz, G., Beerli, A., \& Martín, J. (2003, April). Determinantes psicográficos específicos de la distribución de tareas de reciclado en el hogar [The specific psychographic antecedent of the household tasks]. Paper presented at the II International Workshop on Public and Non-Profit Marketing, Zaragoza, Spain.

Dubois, B., \& Rovira, A. (1999). Comportamiento del consumidor [Consumer behavior]. Madrid, Spain: Prentice Hall Iberia.

Filiatrault, P., \& Ritchie, B. (1980). Joint purchasing decisions: A comparison of influence structure in family and couple decision making. Journal of Consumer Research, 5, 131-140.

Folz, D. (1991). Recycling program design, management, and participation: A national survey of municipal experience. Public Administration Review, 51(3), 222-231.

Folz, D., \& Hazlett, J. (1991). Public participation and recycling performance: Explaining program success. Public Administration Research, 51(6), 526-532.

Foxman, E., Tansuhaj, P., \& Ekstrom, K. (1989). Family members' perceptions of adolescents influence in family decision making. Journal of Consumer Research, 15, 482-491. 
Fuller, D. (1978). Recycling consumer solid waste: A commentary on selected channel alternatives. Journal of Business Research, 6, 17-31.

Gamba, R., \& Oskamp, S. (1994). Factors influencing community residents' participation in commingled curbside recycling programs. Environment and Behavior, 26(5), 587-612.

Hopper, J., \& Nielsen, J. (1991). Recycling as altruistic behavior. Normative and behavioral strategies to expand participation in a com. Environment and Behavior, 23(2), 195-220.

Hornik, J., Cherian, J., Madansky, M., \& Naraya, G. (1995). Determinants of recycling behavior: A synthesis of research results. Journal of Socio-Economics, 24(1), 105-127.

Howenstine, E. (1993). Market segmentation for recycling. Environment and Behavior, 25(1), 86-102.

Hummel, C., Levitt, L., \& Loomis, R. (1978). Perceptions of the energy crisis: Who is blamed and how do citizens react to environmental lifestyle. Environment and Behavior, 10, 37-89.

Katzev, R., Blake, G., \& Messer, B. (1993). Determinants of participation in multi-family recycling programs. Journal of Applied Social Psychology, 23, 374-385.

Loudon, D., \& Della Bitta, A. (1995). Comportamiento del consumidor [Consumer behavior]. Mexico City: McGraw-Hill.

Luyben, P., \& Bailey, J. (1979). Newspaper recycling: The effects of rewards and proximity of containers. Environment and Behavior, 11(4), 539-557.

Mainieri, T., Barnett, E., Trisha, R., Oskamp, S., \& Unipan, J. (1997). Green buying: The influence of environmental concern on consumer behavior. Journal of Social Psychology, 137(2), 189-205.

McCarty, J., \& Shrum, L. (1994). The recycling of solid wastes: Personal values, value orientations, and attitudes about recycling as antecedents of recycling behavior. Journal of Business Research, 30, 53-62.

McCarty, J., \& Shrum, L. (2001). The influence of individualism, collectivism and locus of control on environmental beliefs and behavior. Journal of Public Policy and Marketing, 20(1), 93-105.

Minton, A., \& Rose, R. (1997). The effects of environmental concern on environmentally friendly consumer behavior: An exploratory study. Journal of Business Research, 40, 37-48.

Oskamp, S., Harrington, M., Edwards, T., Sherwood, D., Okuda, S., \& Swanson, D. (1991). Factors influencing household recycling behavior. Environment and Behavior, 23(4), 494-519.

Pickett, G., Kangun, N., \& Grove, S. (1993). Is there a general conserving consumer? A public policy concern. Journal of Public Policy and Marketing, 12, 234-243.

Pieters, R. (1991). Changing garbage disposal patters of consumers: Motivation, ability and performance. Journal of Public Policy and Marketing, 10(2), 59-77.

Pieters, R., Bijmolt, T., Raaij, F., \& Kruijk, M. (1998). Consumers attributions of pro-environmental behavior, motivation, and ability to self and others. Journal of Public Policy and Marketing, 17(2), 215-225.

Roberts, J., \& Bacon, D. (1997). Exploring the subtle relationships between environmental concern and ecologically conscious consumer. Journal of Business Research, 40, 79-89.

Schlegelmilch, B., \& Bohlen, G. (1996). The link between green purchasing decisions and measures of environmental consciousness. European Journal of Marketing, 30(5), 35-55.

Schiffman, L., \& Lazar, L. (1997). Comportamiento del consumidor [Consumer behavior]. México: Prentice Hall Hispanoamericana.

Scholder, E. (1994). Do we know what we need to know? Objective and subjective knowledge effects on pro-ecological behaviors. Journal of Business Research, 30, 43-52.

Schultz, P., \& Stone, W. (1994). Authoritarianism and attitudes toward the environment. Environment and Behavior, 26(1), 25-37. 
860 ENVIRONMENT AND BEHAVIOR / November 2005

Shrum, L., Lowrey, T., \& McCarty, J. (1994). Recycling as a marketing problem: A framework for strategy development. Psychology and Marketing, 11, 393-416.

Solomon, M. (1997). Comportamiento del consumidor. México: Prentice Hall Hispanoamericana.

Solsona, M., \& Treviño, R. (1990). Estructuras familiares en España [Family structure in Spain]. Madrid, Spain: Ed. Ministerio de Asuntos Sociales, Instituto de la Mujer.

Thogersen, J. (1996). Recycling and morality: A critical review of the literature. Environment and Behavior, 28, 536-558.

Van Liere, K., \& Dunlap, R. (1980). The social bases of environmental concern: A review of hypotheses, explanations and empirical evidence. Public Opinion Quarterly, 10, 181-197.

Vining, J., \& Ebreo, A. (1992). Predicting recycling behavior from global and specific environmental attitudes and changes in recycling opportunities. Journal of Applied Social Psychology, 22(20), 1580-1600.

Zikmund, W., \& Stanton, W. (1971). Recycling solid wastes: A channel of distribution problem. Journal of Marketing Research, 35, 34-39.

Zimmer, M., Stafford, T., \& Satfford, M. (1994). Green issues: Dimensions of environmental concern. Journal of Business Research, 30, 63-74. 